\title{
Characterization and Development of EST-SSR Markers in Sweet Potato (Ipomoea batatas (L.) Lam)
}

\author{
Jin-Hee Kim ${ }^{1}$, Jun-Hoi Kim ${ }^{1}$, Won-Sam Jo ${ }^{1}$, Jung-Gwan Ham ${ }^{1}$, Il Kyung Chung ${ }^{2}$ and \\ Kyung-Min Kim ${ }^{*}$ \\ ${ }^{1}$ Division of Plant Biosciences, School of Applied Biosciences, College of Agriculture and Life Science, \\ Kyungpook National University, Daegu 41566, Korea \\ 2 Department of Biotechnology, Catholic University of Daegu, Gyeongsan-Si, Gyeongbuk, 38430, Korea \\ * Correspondence: kkm@knu.ac.kr; Tel.: +82-53-950-5711
}

\begin{abstract}
According to statistics from the Food and Agriculture Organization, the world population will increase to about 91 million (Asia 51 million, Africa 19 million). A rise in the world's population means an increased need for food. However, climate change has caused desertification and unpredictable weather, creating problems in the supply and demand of food. Sweet potato (Ipomoea batatas) is an alternative to solving the food problem, as it is one of the world's most important food crops, especially in developing countries. The tuberous roots of sweet potato are usually used as staple food, animal feed, industrial material, or raw material for alcohol production. In the future, more variations of sweet potato will be needed for breeding this crop. Recently, molecular markers developed for sweet potato have demonstrated good potential for use in genetic selection. In this study, a cDNA library was constructed from the total RNA of sweet potato leaves. A total of 789 copies of the cDNA were cloned in Escherichia coli by employing the pGEM-T Easy vector. Sequencing was carried out by Solgent Co. (Korea). As many as 579 expressed sequence tag-simple sequence repeat (EST-SSR) markers were designed (73.38\%) from the known cDNA nucleotide base sequences. The lengths of the developed EST-SSR markers ranged from 100 to $499 \mathrm{bp}$ (average length $238 \mathrm{bp}$ ). Their motif sequence types were varied, with most being dinucleotides and pentanucleotides, and the most commonly found motifs were CAGAAT $(29.0 \%)$ and TCT (2.8\%). Based on these SSR-containing sequences, 619 pairs of high-quality SSR primers were designed using WebSat and Primer3web. The total number of primers designed was 144. Polymorphism was evident in 82 EST-SSR markers among 20 Korean sweet potato cultivars tested and in 90 EST-SSR markers in the two parents of a mapping population, Yeseumi and Annobeny. In this study, the hexaploid sweet potato $(2 \mathrm{n}=6 \mathrm{x}=90)$ EST-SSR markers were developed in the absence of fullsequence data. Moreover, by acting as a molecular tag for particular traits, the EST-SSR marker can also simultaneously identify information about the corresponding gene. These EST-SSR markers will allow the molecular analysis of sweet potato to be done more efficiently. Thus, we can develop high-quality sweet potato while overcoming the challenges from climate change and other unfavorable conditions.
\end{abstract}

Keywords: EST-SSR marker; hexaploid; sweet potato; polymorphic; sequence

\section{Introduction}

Sweet potato [Ipomoea batatas (L.) Lam.] is a hexaploid $(2 n=6 x=90)$ plant that belongs to the family Convolvulaceae [1-4]. The crop has been grown in USA for more than 300 years since its introduction from South America, its presumed primary center of origin and domestication [5]. Although cultivars grown in the USA before 1920 were direct introductions, modern cultivars are products of open-pollination polycrosses and somatic selections of mutants [6]. According to the Food and Agriculture Organization statistics, the world population will increase to about 91 million (Asia 51 million, Africa 19 million) [7], which means there will be an increased need for food. 
However, climate change has caused desertification and unpredictable weather, creating problems in the supply and demand of food. Sweet potato (Ipomoea batatas) is an alternative to solving the food problem [8-9]. It is one of the world's important food crops, especially in developing countries. Worldwide production of sweet potato in 2014 was more than 104 million tons, of which almost $70 \%$ came from China with a production of around 70 million tons from about 3.3 million ha [7]. The tuberous root of sweet potato, which is involved in carbohydrate storage and vegetative propagation, is a unique organ that has value in biological research of organogenesis and evolution as well as importance in agriculture. The tuberous roots are usually used as staple food, animal feed, industrial material, or raw material for alcohol production. In the future, more variations of sweet potato will be needed for its breeding, because despite its importance, this hexaploid crop is difficult to breed owing to the complexity of its genetics and the lack of genomic resources [10-11]. Traditionally, phenotypic markers have been used to provide descriptors for identifying sweet potato cultivars [12], but they are unreliable owing to their paucity and vulnerability to environmental influence. Molecular markers have great potential to speed up the process of developing improved cultivars; however, little effort has been devoted to the development and application of molecular marker technology for the genetic improvement of sweet potato [13]. Genetic markers offer a number of applications for sweet potato genetic improvement. The randomly amplified polymorphic DNA (RAPD) technique developed in 1990 [14-15] is a powerful molecular marker technique in genetics and plant breeding [16]. RAPD markers have been used on sweet potato to study genetic segregation and linkage [17], construct DNA fingerprints [18], and identify a gene for root-knot nematode resistance [19]. The amplified fragment length polymorphism (AFLP) technique developed in 1995 [20] is based on the selective PCR amplification of small restriction fragments (80-400 bp) from a total digest of genomic DNA. In sweet potato, AFLP markers have been used to study genetic linkage maps [13, 21] and to assess genetic diversity [22]. Expressed sequence tags (ESTs) can be used as a cost-effective and valuable source for the development of molecular markers such as single nucleotide polymorphisms (SNPs) and simple sequence repeats (SSRs). DNA SSRs are widely distributed in both noncoding and transcribed sequences and are commonly known as genomic-SSRs and EST-SSRs [23]. SSRs are useful for many applications in plant genetics and breeding, such as for high-density linkage map construction, genetic diversity analysis, cultivar identification, and markerassisted selection. However, it is still expensive, labor intensive, and time consuming to develop genomic SSR markers. In contrast, EST-SSRs can be rapidly developed from an EST database at lower cost. Moreover, EST-SSRs can also lead to direct gene tagging for quantitative trait locus mapping of agronomically important traits and increase the efficiency of marker-assisted selection [24]. In addition, EST-SSRs show a higher level of transferability to closely related species than do genomic SSR markers [25-28] and can serve as anchor markers for comparative mapping and evolutionary studies [29-30]. Breeding practices for improving the quality of sweet potato are ongoing worldwide, and the recent molecular markers developed for sweet potato have demonstrated good potential to be used in genetic selection [31].

\section{Results}

\subsection{Construction of cDNA Library and Treatment by Restriction Enzymes}

Total RNA was isolated from sweet potato tissue for design of the cDNA library. Electrophoresis analysis showed that the cDNA library amplicon size range was varied. A total of $789 \mathrm{cDNAs}$ were cloned in Escherichia coli by employing the pGEM-T Easy vector. To confirm the ligation of the plasmid and the cDNA, the extracted plasmid from E. coli was cut with a restriction enzyme (EcoRI) and analyzed by $1.0 \%$ agarose gel electrophoresis.

\subsection{Frequency and Distribution of EST-SSR Markers in Sweet Potato}

A total of 789 ESTs with an average length of $283 \mathrm{bp}$ were used to evaluate the presence of SSR motifs. The length of contigs ranged from 100 to $499 \mathrm{bp}$, with those $>250 \mathrm{bp}$ accounting for $75.7 \%$. A 
total of 617 SSRs were identified from 579 unique ESTs. Of these, 31 ESTs contained more than one SSR. All the SSRs showed that the ratio of their unit sizes was not evenly distributed. Among the 617 SSRs, the hexanucleotide repeat motifs were the most abundant $(512,82.98 \%)$, followed by penta- (69, $11.18 \%)$, tri- $(28,4.53 \%)$, di- $(6,0.97 \%)$, and tetranucleotide $(2,0.32 \%)$ repeat motifs (Table 1$)$. As shown in Table 2, the 10-12-bp-long SSRs accounted for 95.5\% of the total SSRs, with the remaining sequences being of 14-20 bp in length (28 SSRs, $4.5 \%$ ). The maximum length of the dinucleotide repeat (TA/TA) and pentanucleotide repeat (GCGAG/CTCGC) was $20 \mathrm{bp}$, respectively. In addition, a total of 94 SSR motifs were identified of which 4, 4, 2, 56, and 28 were di-, tri-, tetra-, penta-, and hexanucleotide repeats, respectively. The CAGAAT/ATTCTG hexanucleotide repeat was the most abundant motif detected in our designed primer $(42,29.0 \%)$, followed by the motifs TCT/AGA (4, $2.8 \%)$, TAATT/AATTA (3, 2.1\%), GAG/CTC (2, 1.4\%), GCGGA/TCCGC (2, 1.4\%), AGAATC/GATTCT $(2,1.4 \%)$, CTCCTG/CAGGAG $(2,1.4 \%)$, and TTGCAG/CTGCAA $(2,1.4 \%)$. The frequency of the remaining 84 types of motifs accounted for $59.1 \%$ (Fig. 1).

Figure 1. Frequency distribution of EST-derived SSRs of sweetpotato based on types of motif sequence. $\mathrm{X}$-axis is motif sequence types, and Y-axis represents the frequency of SSRs of a given motif sequence type.

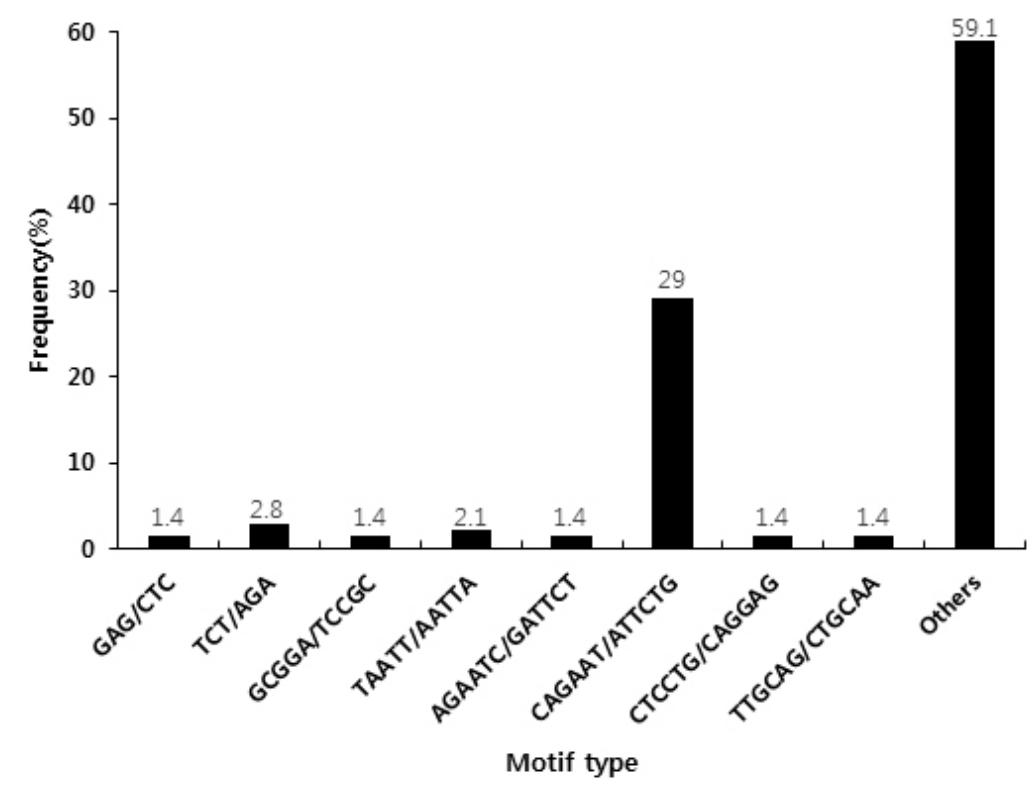

Table 1. Summarization of EST-SSR search results.

\begin{tabular}{ll}
\hline \multicolumn{1}{c}{ Searched items } & Number \\
\hline Total number of sequences examined & 789 \\
Total size of examined sequences (bp) & 174,755 \\
Total number of identified SSRs & 617 \\
Number of SSR-containing sequences & 579 \\
Number of sequences containing more than 1 SSR & 31 \\
Dinucleotide & 6 \\
Trinucleotide & 28 \\
Tetranucleotide & 2 \\
Pentanucleotide & 69 \\
Hexanucleotide & 512 \\
\hline
\end{tabular}


Table 2. EST-SSRs based on the number of repeat units for length distribution.

\begin{tabular}{ccccccc}
\hline Repeat number & Di- & Tri- & Tetra- & Penta- & Hexa- & Total \\
\hline 2 & 0 & 0 & 0 & 68 & 512 & 580 \\
3 & 0 & 0 & 2 & 0 & 0 & 2 \\
4 & 0 & 4 & 0 & 1 & 0 & 5 \\
5 & 3 & 24 & 0 & 0 & 0 & 27 \\
6 & 0 & 0 & 0 & 0 & 0 & 0 \\
7 & 2 & 0 & 0 & 0 & 0 & 2 \\
8 & 0 & 0 & 0 & 0 & 0 & 0 \\
9 & 0 & 0 & 0 & 0 & 0 & 0 \\
10 & 1 & 0 & 0 & 0 & 0 & 1 \\
\hline
\end{tabular}

\subsection{Primer Design and Evaluation of EST-SSR Markers in Cultivated Sweet Potato}

In order to ensure the uniqueness of the newly designed EST-SSR primer pairs, 579 potential unique SSR-containing sequences were analyzed. Based on these SSR-containing sequences, 619 pairs of high-quality SSR primers were designed using WebSat (http://www.wsmartins.net/websat/) and Primer3web version 4.0.0 (http://bioinfo.ut.ee/primer3/). The total number of designed primers was 144. Of these, 4, 8, 2, 59, and 71 were for di-, tri-, tetra-, penta- and hexanucleotide repeats, respectively (Fig. 2). After being tested in 20 Korean sweet potato cultivars, 119 primer pairs (82.6\%) were successfully amplified. Of these 119 working primer pairs, only 76 amplified PCR products were of the expected sizes. Twenty-four of the other 43 primers produced larger than expected PCR products and 19 gave smaller than expected results. The 144 primers were used for further validation in the Yeseumi and Annobeny cultivars, and 106 primer pairs (73.6\%) were successfully amplified. Examples of the PCR products amplified in Yeseumi and Annobeny, and in the 20 cultivars, are shown in Fig. 2.

Figure 2. Polymorphic primer pairs and number of designed primer pairs. The figure was indicated number of primer pairs designed (black columns), primer pairs amplified (gray columns), polymorphic loci in two parents Yeseumi and Annobeny (dotted white columns) and polymorphic loci in the twenty sweetpotato cultivars (white columns).

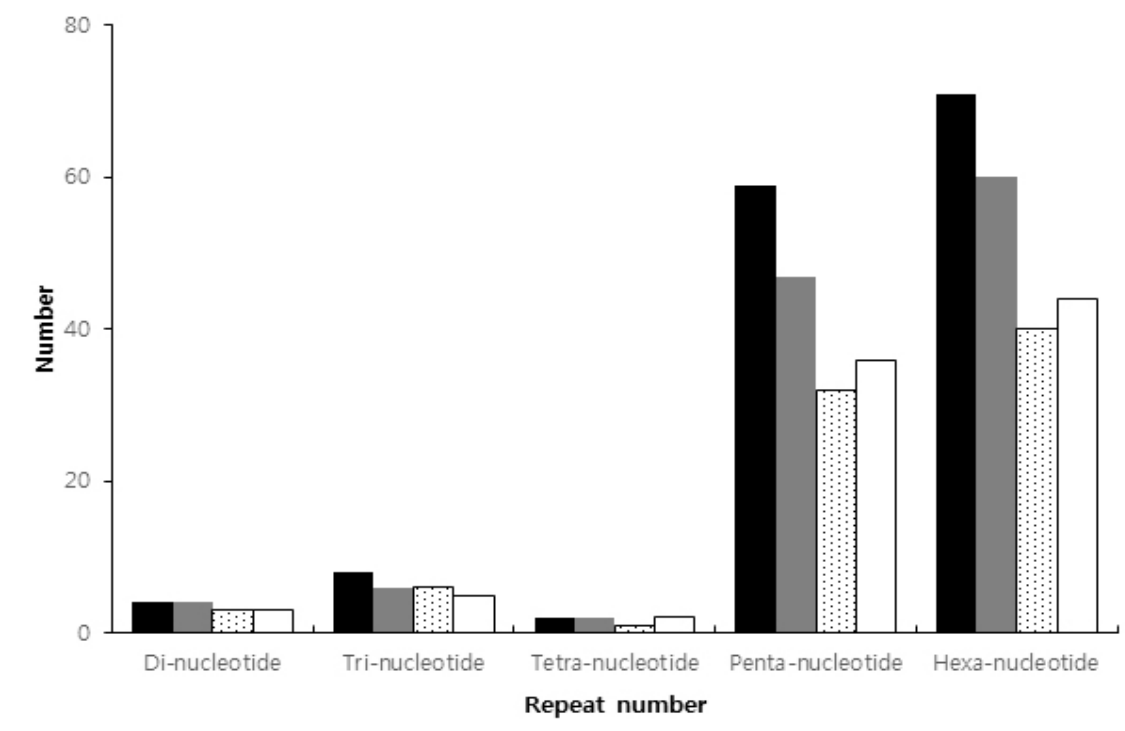

\subsection{Polymorphism of EST-SSR Markers in Cultivated Sweet Potato}

The polymorphism assessment was examined in 20 Korean sweet potato cultivars, as well as Yeseumi and Annobeny. Among the 119 effective SSR primer pairs amplified from the 20 cultivars, $82(68.9 \%)$ were polymorphic (observed for 3 di-, 6 tri-, 1 tetra-, 32 penta-, and 40 hexanucleotide 
repeats). Among the 106 effective SSR primer pairs amplified from cultivars Yeseumi and Annobeny, $90(84.9 \%)$ were polymorphic (observed for 3 di-, 5 tri-, 2 tetra-, 36 penta-, and 44 hexanucleotide repeats) (Fig. 3).

Figure 3. SSR primer pairs for Amplification of PCR products. A: PCR products amplified by 20 primer pairs from Yeseumi (lanes 1) and Annobeny (lanes 2). B: PCR products amplified by 2 primer pairs from twenty sweetpotao cultivars. DNA samples from left to right are Yulmi (lanes 1), Jeonmi (lanes 2), Gogeonmi (lanes 3), Jungmi (lanes 4), Sincheonmi (lanes 5), Geonhwangmi (lanes 6), Yeonmi (lanes 7), Geonmi (lanes 8), Yeonjami (lanes 9), Sinjami (lanes 10), Sinyulmi (lanes 11), Helseumi (lanes 12), Geonpungmi (lanes 13), Yeseumi (lanes 14), Hayanmi (lanes 15), Jinhongmi (lanes 16), Juhwangmi (lanes 17), Dahomi (lanes 18), Simgeonmi (lanes 19), Yeonhwangmi (lanes 20). Standard size markers are given on left side.

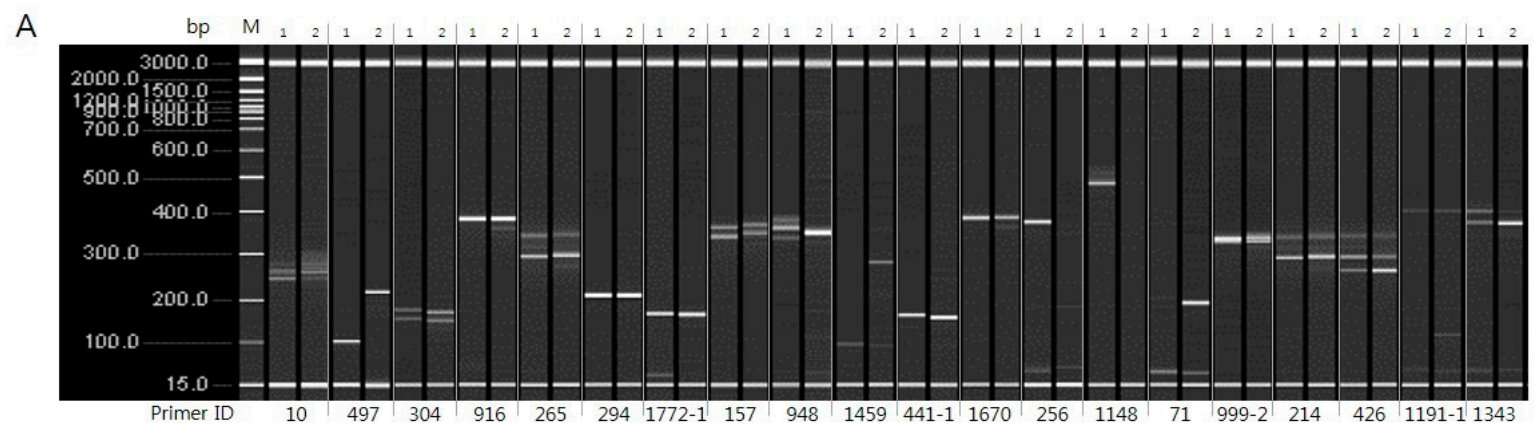

B

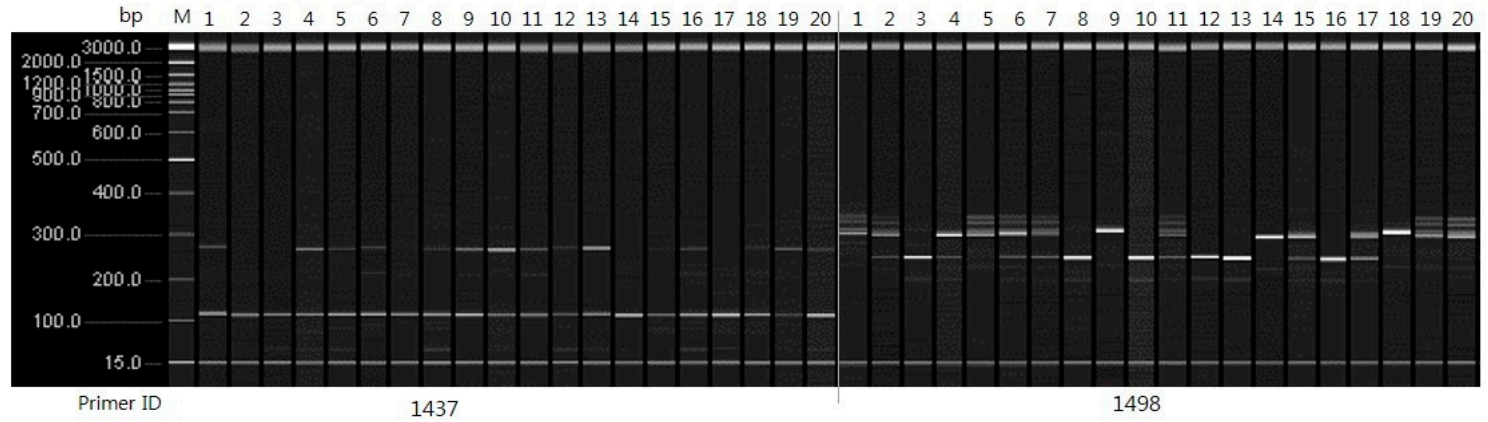

\section{Discussion}

In this study, we developed EST-SSR markers from the genome sequence of sweet potato. Generally, molecular analysis in sweet potato is carried out by using SSR markers and inter-simple sequence repeat markers [32-33]. However, SSR markers do not represent gene function. Recently, the development of an EST-SSR marker in sweet potato was reported, using a next-generation sequencing [31] method; namely, isolation of microsatellite markers from genomic sequences. Compared with traditional methods such as construction of a SSR-enriched DNA library followed by cloning and sequencing using the Sanger method, next-generation sequencing has the advantages of time and cost savings [34-37]. Nevertheless, although studies using next-generation sequencing have resulted in more than 59 million sequencing reads, it was reported that only 92 primer pairs were successfully employed [31]. In our study, a total of 789 potential unique EST sequences (about $174.7 \mathrm{~kb})$ were used for searching SSRs, where 579 ESTs $(73.4 \%)$ contained SSR motifs, generating 617 unique SSRs. Among the 144 designed primers, 119 (82.6\%) were successfully amplified in sweet potato, which is a high efficiency rate. In this study, the hexanucleotide repeats were the most frequent motif type, followed by penta-, tri-, di-, and tetranucleotides (Table 1). However, in another report that used a total of 87,492 potential unique EST sequences (about $58.7 \mathrm{Mb}$ ) to search for SSRs in sweet potato, of which 7,163 ESTs (8.2\%) contained SSR motifs, generating 8,294 unique SSRs, the trinucleotide repeat was found to be the most abundant, followed by di-, tetra-, penta-, and hexanucleotides [38]. In our study, 82 EST-SSR markers among the 20 sweet potato cultivars were polymorphic, whereas 90 EST-SSR markers were polymorphic among the Yeseumi and Annobeny 
cultivars. In the absence of full-sequence data from sweet potato cultivars in Korea, we had developed fixed Korean sweet potato EST-SSR markers instead. This would necessitate a comparison of our fixed EST-SSR markers in more Korean and other cultivars. The development of EST-SSR markers has gained traction in recent years. Qureshi et al. (2004) [39] developed 84 EST-SSR primers of Gossypium arboreum var. indium using 9,948 sequence data, and Kim et al. (2010) [40] used 30 EST-SSR markers for analysis of Rosa hybrida L. Oh et al. (2010) [41] reported the phylogenetic analysis of Daucus carota var. sativa as well as analysis of various characteristic molecular markers, using 50 markers based on EST sequences. Moreover, besides acting as a molecular tag for particular traits, EST-SSR markers can also simultaneously identify information about the corresponding gene. Thus, by developing EST-SSR markers, the molecular analysis of sweet potato could be done more efficiently. EST-SSR markers can also be used in the construction of sweet potato maps. Thus, we can develop high-quality sweet potato while overcoming the challenges from climate change and other unfavorable conditions.

\section{Materials and Methods}

\subsection{Plant Materials}

In the present study, the 20 Korean sweet potato cultivars and two parents of a mapping population, Yeseumi and Annobeny, were provided by the Rural Development Administration (Jeollabuk, Korea) (Table 3).

Table 3. Sweet potato cultivars used for EST-SSR marker validation and evaluation.

\begin{tabular}{lll}
\hline Cultivar name & Origin & Description \\
\hline Yeseumi & Korea & Improved variety, mapping parent \\
Annobeny & Japan & Introduced variety, mapping parent \\
Yulmi & Korea & Improved variety \\
Jeonmi & Korea & Improved variety \\
Gogeonmi & Korea & Improved variety \\
Jungmi & Korea & Improved variety \\
Sincheonmi & Korea & Improved variety \\
Geonhwangmi & Korea & Improved variety \\
Yeonmi & Korea & Improved variety \\
Geonmi & Korea & Improved variety \\
Yeonjami & Korea & Improved variety \\
Sinjami & Korea & Improved variety \\
Sinyulmi & Korea & Improved variety \\
Geonpungmi & Korea & Improved variety \\
Helseumi & Korea & Improved variety \\
Hayanmi & Korea & Improved variety \\
Jinhongmi & Korea & Improved variety \\
Juhwangmi & Korea & Improved variety \\
Dahomi & Korea & Improved variety \\
Simgeonmi & Korea & Improved variety \\
Yeonhwangmi & Korea & Improved variety \\
\hline
\end{tabular}

\subsection{DNA and RNA Extraction}

Total RNA was extracted from leaf tissue of sweet potato using the RNeasy Mini Kit (Qiagen, Hilden, Germany) according to the manufacturer's instructions. In brief, RLT buffer (Qiagen) containing $\beta$-mercaptoethanol was thoroughly mixed with the sample. The mixture was then transferred to a QIAshredder spin column and centrifuged for $5 \mathrm{~min}$. The supernatant was 
transferred to a new $1.5 \mathrm{~mL}$ tube and an equal volume of $70 \%$ ethanol was added. The mixture was immediately applied to an RNeasy spin column that was then centrifuged for 1 min at 13,000 rpm. The flow-through was discarded and the column was washed by adding $500 \mu \mathrm{L}$ of RPE buffer (Qiagen) followed by centrifugation for $1 \mathrm{~min}$ at 13,000 rpm. The flow-through was again discarded and the washing process was repeated. Finally, the RNA was suspended in $30 \mu \mathrm{L}$ of RNase-free water. The concentration of genomic DNA was checked using a Nano Drop 2000 spectrophotometer.

The genomic DNA was extracted from leaf tissue of sweet potato using a modified cetyl trimethylammonium bromide (CTAB) method. Samples of $20-100 \mathrm{mg}$ of leaves were placed respectively in a $2 \mathrm{~mL}$ tube, containing a tungsten ball and frozen liquid nitrogen, for $5 \mathrm{~min}$. The samples were then ground into powder using a TissueLyser apparatus (Qiagen) at 20 vibrations per second for $30 \mathrm{~s}$. Next, $700 \mu \mathrm{L}$ of $2 \times$ CTAB buffer ( $2 \%$ CTAB, $0.1 \mathrm{M}$ Tris, $\mathrm{pH}$ 8.0, $1.4 \mathrm{M} \mathrm{NaCl}, 1 \%$ polyvinylpyrrolidone) was added to the tubes. The samples were then vortexed, after which the tubes were incubated in a water bath at $65^{\circ} \mathrm{C}$ for $20 \mathrm{~min}$. After removal from the water bath, $700 \mu \mathrm{L}$ of phenol:chloroform:isoamyl alcohol (25:24:1) was added to the samples and the tubes were shaken for $20 \mathrm{~min}$ at room temperature before centrifugation. Next, $500 \mu \mathrm{L}$ of the supernatant was removed to a new $1.5 \mathrm{~mL}$ tube and $350 \mu \mathrm{L}$ of isopropanol was added. The tubes were then shaken for $5 \mathrm{~min}$, followed by freezing at $-72^{\circ} \mathrm{C}$ for $2 \mathrm{~h}$. Subsequently, the samples were melted slowly and centrifuged at 13,000 rpm for $10 \mathrm{~min}$. After discarding the supernatant, the pellet was dried at room temperature after washing two times in $70 \%$ ethanol. Finally, $20 \mu \mathrm{L}$ of distilled water was added to each tube and the concentration of genomic DNA was checked using a Nano Drop 2000 spectrophotometer.

\subsection{Construction of the cDNA Library}

The cDNA library was synthesized by using a cDNA synthesis kit (TaKaRa, Shiga, Japan). In brief, 2,000 ng of template RNA was added to a mixture composed of $4 \mu \mathrm{L}$ of $5 \times 1$ st strand synthesis buffer, $1 \mu \mathrm{L}$ of dNTP mixture $(10 \mathrm{mM}), 1 \mu \mathrm{L}$ of RNase inhibitor $(20 \mathrm{U} / \mu \mathrm{L}), 2 \mu \mathrm{L}$ of oligo(dT) 18 primer $(1 \mu \mathrm{g} / \mu \mathrm{L})$, and $1 \mu \mathrm{L}$ of M-MLV reverse transcriptase, in a total volume of $20 \mu \mathrm{L}$. The mixture was then subjected to the following 1st strand cDNA reaction conditions: room temperature for $10 \mathrm{~min}$, $42^{\circ} \mathrm{C}$ for $1 \mathrm{~h}$, and $80^{\circ} \mathrm{C}$ for $5 \mathrm{~min}$. Next, the mixture was mixed with $30 \mu \mathrm{L}$ of $5 \times 2$ nd strand synthesis buffer and $3 \mu \mathrm{L}$ of dNTP mixture $(10 \mathrm{mM})$, after which the volume was adjusted to $89 \mu \mathrm{L}$ with nuclease-free water. Then, $2 \mu \mathrm{L}$ of $E$. coli DNA polymerase I $(20 \mathrm{U} / \mu \mathrm{L})$ and $2 \mu \mathrm{L}$ of $E$. coli RNase $\mathrm{H} / E$. coli DNA ligase mixture were added, and the mixture was incubated at $16^{\circ} \mathrm{C}$ for $2 \mathrm{~h}$ and $70^{\circ} \mathrm{C}$ for 10 min. Subsequently, $4 \mu \mathrm{L}$ of T4 DNA ligase $(1 \mathrm{U} / \mu \mathrm{L})$ was added to the solution and incubation was carried out at $37^{\circ} \mathrm{C}$ for $10 \mathrm{~min}$. The reaction was stopped by the addition of $12 \mu \mathrm{L}$ of stop solution (0.2 M ethylenediaminetetraacetic acid and $2 \mathrm{mg} / \mathrm{mL}$ glycogen, $\mathrm{pH}$ 8.0). To purify the cDNA, an equal volume of phenol:chloroform:isoamyl alcohol (25:24:1) was then added to the solution, after which the mixture was vortex-mixed and then centrifuged at 13,000 rpm for $10 \mathrm{~min}$. The upper layer was transferred to a new $1.5 \mathrm{~mL}$ tube and an equal volume of chloroform:isoamyl alcohol (24:1) was added. The tube was stirred for $1 \mathrm{~min}$ and then centrifuged at 13,000 rpm for $10 \mathrm{~min}$. The upper layer was transferred to a new $1.5 \mathrm{~mL}$ tube and an equal volume of $4 \mathrm{M}$ ammonium acetate was added, followed by an equal volume of isopropanol. Following incubation at $-20^{\circ} \mathrm{C}$ for $30 \mathrm{~min}$, the mixture was centrifuged at 13,000 rpm for $10 \mathrm{~min}$. The supernatant was subsequently removed, $1 \mathrm{~mL}$ of ethyl alcohol (70\%) was added to the pellet, and the suspension was centrifuged at 13,000 rpm for $5 \mathrm{~min}$. The cDNA was finally suspended in nuclease-free water. The cDNA was A-tailed in a total $10 \mu \mathrm{L}$ reaction volume by adding $1 \mu \mathrm{L}$ of $10 \times$ buffer, $0.6 \mu \mathrm{L}$ of $\mathrm{MgCl}_{2}(25 \mathrm{mM}), 0.4 \mu \mathrm{L}$ of dATP $(5 \mathrm{mM} / \mu \mathrm{L})$, and $1 \mu \mathrm{L}$ of Taq polymerase $(5 \mathrm{U} / \mu \mathrm{L})$. The mixture was incubated at $70^{\circ} \mathrm{C}$ for $30 \mathrm{~min}$ and then purified using ethyl alcohol.

\section{4. cDNA Library Transformation to the Vector}

The cDNA library was ligated to the pGEM-T Easy vector (Promega, Madison, WI, USA) by mixing $50 \mathrm{ng}$ of pGEM-T Easy Vector, $5 \mu \mathrm{L}$ of $2 \times$ ligation buffer, and $1 \mathrm{U}$ of T4 DNA ligase in a $10 \mu \mathrm{L}$ reaction volume. After ligation at room temperature for $1 \mathrm{~h}, 2 \mu \mathrm{L}$ of the product and $50 \mu \mathrm{L}$ of $E$. coli 
DH5 $\alpha$ competent cells were mixed and incubated on ice for $20 \mathrm{~min}$, followed by heat shock at $42^{\circ} \mathrm{C}$ for $45 \mathrm{~s}$ and cooling on ice for $2 \mathrm{~min}$. Then, $950 \mu \mathrm{L}$ of Luria-Bertani (LB) broth was added and the cells were incubated at $37^{\circ} \mathrm{C}$ for $90 \mathrm{~min}$ with shaking at $200 \mathrm{rpm}$. Subsequently, the culture was plated on LB agar containing $100 \mathrm{ppm}$ ampicillin, $0.5 \mathrm{mM}$ isopropyl $\beta$-D-1-thiogalactopyranoside, and 80 $\mu \mathrm{g} / \mathrm{mL}$ X-Gal for $12 \mathrm{~h}$ at $37^{\circ} \mathrm{C}$. The positive colonies identified after blue-white selection were cultured in $5 \mathrm{~mL}$ of $\mathrm{LB}$ broth at $37^{\circ} \mathrm{C}$ for $16 \mathrm{~h}$ with shaking at $180 \mathrm{rpm}$. Following incubation, the culture was centrifuged at 3,500 rpm for $10 \mathrm{~min}$ and the plasmid DNA was extracted using a QIAprep Spin Miniprep Kit (Qiagen). After removing the supernatant, the cell pellet was suspended in $250 \mu \mathrm{L}$ of P1 buffer and transferred to a $1.5 \mathrm{~mL}$ tube. Next, $250 \mu \mathrm{L}$ of P2 buffer and $350 \mu \mathrm{L}$ of N3 buffer were added before centrifugation at 13,000 rpm for $10 \mathrm{~min}$. The supernatant was transferred to a QIAprep spin column that was then centrifuged at 13,000 rpm for $1 \mathrm{~min}$. After discarding the flow-through, $500 \mu \mathrm{L}$ of PB buffer was added to the column, which was then centrifuged at 13,000 rpm for $1 \mathrm{~min}$. The column was washed with $750 \mu \mathrm{L}$ of PE buffer and the plasmid DNA was retrieved in $30 \mu \mathrm{L}$ of nuclease-free water after a final centrifugation of the column at 13,000 rpm for $1 \mathrm{~min}$.

\subsection{DNA Sequencing and Primer Design}

The plasmid DNA sequence was analyzed by SolGent (SolGent Co., Daejeon, Korea), which verified that the cDNA was inserted into the pGEM-T Easy vector. After analysis of the DNA sequence, cDNA consensus was identified using the basic local alignment search tool (http://blast.ncbi.nlm.nih.gov/Blast.cgi). The EST-SSR markers were designed using the microsatellite analysis program WebSat and Primer3web version 4.0.0. The SSR sites analyzed were used to prepare the forward and reverse primers. Primer design was based on the following core criteria: (1) primer length ranging from 18 to $27 \mathrm{bp}$; (2) melting temperature between $55^{\circ} \mathrm{C}$ and $62^{\circ} \mathrm{C}$ with $60^{\circ} \mathrm{C}$ as the optimum; (3) PCR product size ranging from 150 to $500 \mathrm{bp}$; and (4) GC\% content between $20 \%$ and $60 \%$, with an amplification rate larger than $80 \%$.

\subsection{PCR Amplification and Polymorphism Analysis}

PCR was conducted using a UNO II thermocycler (Biometra GmbH, Göttingen, Germany). As a

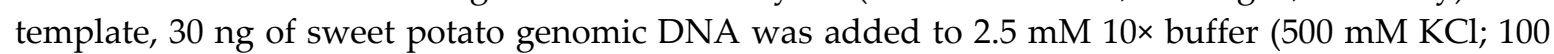
$\mathrm{mM}$ Tris- $\mathrm{HCl}, \mathrm{pH} 8.3 ; 15 \mathrm{mM} \mathrm{MgCl}_{2}$ ), 20 pmol dNTP mixture, 20 pmol SSR marker primer, and $1 \mathrm{U}$ of Taq DNA polymerase. Initial denaturation was carried out at $96^{\circ} \mathrm{C}$ for $5 \mathrm{~min}$, and denaturation was at $96^{\circ} \mathrm{C}$ for $1 \mathrm{~min}$. The annealing temperature ranged from $54.5^{\circ} \mathrm{C}$ to $61.5^{\circ} \mathrm{C}$ for $30 \mathrm{~s}$, and extension was at $72^{\circ} \mathrm{C}$ for $1 \mathrm{~min}$. The final extension temperature was $72^{\circ} \mathrm{C}$ for $5 \mathrm{~min}$. After the PCR was complete, $5 \mu \mathrm{L}$ of the product was loaded onto a QIAxcel capillary gel electrophoresis system (Qiagen) for analysis.

\section{References}

1. Jones, A. Cytological observations and fertility measurements of sweetpotato (Ipomoea batatas (L) Lam). In: Proceedings of the American Society for Horticultural Science. 701 NORTH SAINT ASAPH STREET, ALEXANDRIA, VA 22314-1998: AMER SOC HORTICULTURAL SCIENCE, 1965. p. 527-\&.

2. Martin, F.W. Self-and interspecific incompatibility in the Convolvulaceae. Botanical Gazette, 1970, 139-144.

3. Ting, Y.C; Kehr, A.E. Meiotic studies in the sweet potato (Ipomoea batatas Lam.). Journal of Heredity, 1953, 44.5: 207-211.

4. Austin, D.F. The taxonomy, evolution and genetic diversity of sweet potatoes and related wild species. Exploration, maintenance, and utilization of sweetpotato genetic resources. International Potato Center, Lima, Peru, 1988, 27-60.

5. Bohac, J.R.; Dukes, P.D.; Austin, D.F. Sweet potato. Evolution of crop plants, ed, 1995, 2: 57-62. 
6. Jones, A.; Dukes, P.D.; Schalk, J.M. Sweet potato breeding. Breeding vegetable crops. AVI Publishing Co., Westport, CT, 1986, 1-35.

7. The Food and Agriculture Organization. http://faostat.fao.org/ (10.09.2016)

8. Mukhopadhyay, S.K.; Chattopadhyay, A.; Chakraborty, I.; Bhattacharya, I. Crops that feed the world 5. Sweetpotato. Sweetpotatoes for income and food security. Food Security, 2011, 3.3: 283-305.

9. LIU Q.C. IMPORTANCE OF SWEETPOTATO IN THE SECURITY OF FOOD AND ENERGY IN CHINA [J]. Science \& Technology Review, 2004, 9: 008.

10. Cervantes-Flores, J.C.; Yencho, G.C.; Kriegner, A.; Pecota, K.V.; Faulk, M.A.; Mwanga, R.O.; Sosinski, B.R. Development of a genetic linkage map and identification of homologous linkage groups in sweetpotato using multiple-dose AFLP markers. Molecular Breeding, 2008, 21.4: 511-532.

11. Kriegner, A.; Cervantes, J.C.; Burg, K.; Mwanga, R.O.; Zhang, D. A genetic linkage map of sweetpotato [Ipomoea batatas (L.) Lam.] based on AFLP markers. Molecular Breeding, 2003, 11.3: 169-185.

12. Huaman, Z.; Collins, W.; De la Puente, F. Genetic conservation of sweet potato in Latin America and the genebank at CIP. Diversity, 1991, 7.1\&2: 47-48

13. Kriegner, A.; Cervantes, J.C.; Burg, K c Mwanga, R.O.; Zhang, D. A genetic linkage map of sweetpotato [Ipomoea batatas (L.) Lam.] based on AFLP markers. Molecular Breeding, 2003, 11.3: 169-185.

14. Welsh, J.; McClelland, M. Fingerprinting genomes using PCR with arbitrary primers. Nucleic acids research, 1990, 18.24: 7213-7218.

15. Williams, J.G.; Kubelik, A.R.; Livak, K.J.; Rafalski, J.A.; Tingey, S.V. DNA polymorphisms amplified by arbitrary primers are useful as genetic markers. Nucleic acids research, 1990, 18.22: 6531-6535.

16. Tingey, S.V.; Rafalski, J.A.; Williams, J.G.K. Genetic analysis with RAPD markers. Application of RAPD Technology to Plant Breeding. In: Joint Plant Breeding Symposia Series CSSA/ASHS/AGA. 1992.

17. Hong, L.L. Segregation and Genetic Linkage Analysis of Random Amplified Polymorphic DNA Markers in Sweetpotato (Ipomoea Batatas (L.) LAM). 1994.

18. Connolly, A.G.; Godwin, I.D.; Cooper, M.; DeLacy, I.H. Interpretation of randomly amplified polymorphic DNA marker data for fingerprinting sweet potato (Ipomoea batatas L.) genotypes. Theoretical and applied genetics, 1994, 88.3-4: 332-336.

19. Ukoskit, K.; Thompson, P.G.; Watson, C.E.; Lawrence, G.W. Identifying a randomly amplified polymorphic DNA (RAPD) marker linked to a gene for root-knot nematode resistance in sweetpotato. Journal of the American Society for Horticultural Science, 1997, 122.6: 818-821.

20. Vos, P.; Hogers, R.; Bleeker, M.; Reijans, M.; Lee, T.V.D.; Hornes, M.; Frijters, A.; Pot, J.; Peleman, J.; Kuiper M.; Zabeau, M. AFLP: a new technique for DNA fingerprinting. Nucleic acids research, 1995, 23.21: 44074414 .

21. Cervantes-Flores, J.C.; Yencho, G.C.; Kriegner, A.; Pecota, K.V.; Faulk, M.A.; Mwanga, R.O.; Sosinski, B.R. Development of a genetic linkage map and identification of homologous linkage groups in sweetpotato using multiple-dose AFLP markers. Molecular Breeding, 2008, 21.4: 511-532.

22. Zhang, D.; Cervantes, J.; Huamán, Z.; Carey, E.; Ghislain, M. Assessing genetic diversity of sweet potato (Ipomoea batatas (L.) Lam.) cultivars from tropical America using AFLP. Genetic Resources and Crop Evolution, 2000, 47.6: 659-665.

23. Morgante, M.; Hanafey, M.; Powell, W. Microsatellites are preferentially associated with nonrepetitive DNA in plant genomes. Nature genetics, 2002, 30.2: 194-200.

24. Gupta, P.K.; Rustgi, S. Molecular markers from the transcribed/expressed region of the genome in higher plants. Functional \& integrative genomics, 2004, 4.3: 139-162.

25. Saha, M.C.; Cooper, J.D.; Mian, M.R.; Chekhovskiy, K.; May, G.D. Tall fescue genomic SSR markers: development and transferability across multiple grass species. Theoretical and applied genetics, 2006, 113.8: 1449-1458.

26. Scott, K.D.; Eggler, P.; Seaton, G.; Rossetto, M.; Ablett, E.M.; Lee, L.S.; Henry, R.J. Analysis of SSRs derived from grape ESTs. Theoretical and applied genetics, 2000, 100.5: 723-726.

27. Eujayl, I.; Sledge, M.K.; Wang, L.; May, G.D.; Chekhovskiy, K.; Zwonitzer, J.C.; Mian, M. A.R. Medicago truncatula EST-SSRs reveal cross-species genetic markers for Medicago spp. Theoretical and Applied Genetics, 2004, 108.3: 414-422.

28. Zhang, L.Y.; Bernard, M.; Leroy, P.; Feuillet, C.; Sourdille, P. High transferability of bread wheat ESTderived SSRs to other cereals. Theoretical and Applied Genetics, 2005, 111.4: 677-687. 
29. Varshney, R.K.; Graner, A.; Sorrells, M.E. Genic microsatellite markers in plants: features and applications. TRENDS in Biotechnology, 2005, 23.1: 48-55.

30. Varshney, R.K.; Sigmund, R.; Börner, A.; Korzun, V.; Stein, N.; Sorrells, M.E.; Langridge, P.; Graner, A. Interspecific transferability and comparative mapping of barley EST-SSR markers in wheat, rye and rice. Plant Science, 2005, 168.1: 195-202

31. Wang, Z.; Fang, B.; Chen, J.; Zhang, X.; Luo, Z.; Huang, L.; Chen, X; Li, Y. De novo assembly and characterization of root transcriptome using Illumina paired-end sequencing and development of cSSR markers in sweetpotato (Ipomoea batatas). BMC genomics, 2010, 11.1: 1.

32. Koussao, S.; Gracen, V.; Asante, I.; Danquah, E. Y.; Ouedraogo, J.T.; Baptiste, T.J.; Vianney, T.M. Diversity analysis of sweet potato (Ipomoea batatas [L.] Lam) germplasm from Burkina Faso using morphological and simple sequence repeats markers. African Journal of Biotechnology, 2014, 13.6: 729-742.

33. Hu, J.; Nakatani, M.; Lalusin, A.G.; Kuranouchi, T.; Fujimura, T. Genetic analysis of sweetpotato and wild relatives using inter-simple sequence repeats (ISSRs). Breeding science, 2003, 53.4: 297-304.

34. Abdelkrim, J.; Robertson, B.C.; Stanton, J.A.; Gemmell, N.J. Fast, cost-effective development of speciesspecific microsatellite markers by genomic sequencing. Biotechniques, 2009, 46.3: 185.

35. Malausa, T.; Gilles, A.; Meglecz, E.; Blanquart, H.; Duthoy, S.; Costedoat, C.; Dubut, V.; Pech, N.; Castagnone-Sereno, P.; Delye, C.; Feau, N.; Frey, P.; Gauthier, P.; Guillemaud, T.; Hazard, L.; Corre, V.; Lung-Escarmant, B.; G.Male, P.J.; Ferreira, S.; Martin, J.F. High-throughput microsatellite isolation through 454 GS-FLX Titanium pyrosequencing of enriched DNA libraries. Molecular Ecology Resources, 2011, 11.4: 638-644.

36. Santana, Q.C.; Coetzee, M.P.; Steenkamp, E.T.; Mlonyeni, O.X.; Hammond, G.N.; Wingfield, M.J.; Wingfield, B.D. Microsatellite discovery by deep sequencing of enriched genomic libraries. Biotechniques, 2009, 46.3: 217.

37. Zalapa, J.E.; Cuevas, H.; Zhu, H.; Steffan, S.; Senalik, D.; Zeldin, E.; McCown, B.; Harbut, R.; Simon, P. Using next-generation sequencing approaches to isolate simple sequence repeat (SSR) loci in the plant sciences. American Journal of Botany, 2012, 99.2: 193-208.

38. Wang, Z.; Li J.; Luo, Z.; Huang, L.; Chen, X.; Fang, B.; Li, Y.; Chen, J.; Zhang X. Characterization and development of EST-derived SSR markers in cultivated sweetpotato (Ipomoea batatas). BMC plant biology, 2011, 11.1: 1.

39. Qureshi, S.N.; Saha, S.; Kantety, R.V.; Jenkins, J.N.; Saha, S. Molecular biology and physiology: EST-SSR: a new class of genetic markers in cotton. In: Journal of CottonScience. 2004, 8: 112-123

40. Kim, J.K.; Ahn, D.C.; Oh, H.J.; Kim, K.H.; Choi, Y.M.; Oh, S.Y.; Kang, N.J.; Jeong, B.R.; Kim, Z.H.; Park, Y.H. Skewed inheritance of EST-SSR alleles in reciprocal crosses of cut roses. Korean Journal of Horticultural Science \& Technology, 2010, 28.4: 618-626.

41. Oh, G.D.; Hwang, E.M.; Shim, E.J.; Jeon, S.J.; Park, Y.D. EST profiling for seed-hair characteristic and development of EST-SSR and SNP markers in carrot. Korean Journal of Horticultural Science and Technology, 2010, 28.6: 1025-1038.

(C) 2016 by the authors; licensee Preprints, Basel, Switzerland. This article is an open access article distributed under the terms and conditions of the Creative Commons by Attribution (CC-BY) license (http://creativecommons.org/licenses/by/4.0/). 